\title{
PENINGKATAN KUALITAS PEMBELAJARAN BIOLOGI DENGAN METODE KOOPERATIF DI PRODI PEND. FISIKA FKIP UHN MEDAN
}

\author{
Mariana br Surbakti ${ }^{1}$, Poltak Panjaitan ${ }^{2}$ \\ Fakultas Keguruan Ilmu Pendidikan Universitas HKBP Nommensen \\ Email: marianasurbakti1972@gmail.com
}

\begin{abstract}
The purpose of this study was to 1) determine student learning outcomes through the Inquiry learning model on metabolic material, 2) know the learning activities of students who were taught with Inquiry learning models in Biology courses, 3) know the psychomotor attitudes of students who were taught with models cooperative learning on metabolic material. This research is an experimental research This research was conducted on physics study students at T.P. 2018/2019. The learning model used is inquiry model in the experimental class and conventional model in the control class.

The results showed that: The results of the average value in the control class were: pretest $=45,517$ and posttest $=61,896$ The results of the average value in the experimental class are: pretest $=48.333$ and post test $=80.833$ Obtained data $X=80.83 ; \mathrm{S}=12.32 ; \mathrm{L}$ hitung $=0.0937 ; \mathrm{L}$ table $=0.161$;

then: $\mathrm{L}$ calculate $<\mathrm{L}$ table, then posttest data Experiment class is normally distributed

From the results of the statistical calculation above $t$ arithmetic $=$ and $t$ table $=2.003$ so as to obtain the value of $-2.003 \quad<2.003$ then $\mathrm{H} 0$ is accepted, meaning that the initial ability of students in the experimental class is the same as the initial ability of students in the control class.

From the results of the statistical calculation above $t$ arithmetic $=$ and $t$ table $=1.6715$ to obtain a value of $\mathrm{t}>\mathrm{t}$ table ie $>1.6715$ then $\mathrm{H} 0$ is rejected and $\mathrm{Ha}$ is accepted meaning there is a significant influence on the use of cooperative learning models on student learning outcomes. The coefficient of linear regression direction $(\mathrm{b})=0.85$ which is positive. This means that the learning outcomes of experimental class student increase due to the influence of the cooperative learning model used in the teaching and learning process in the class.
\end{abstract}

Keywords: Model Pembelajaran Inkuiri, Metabolisme, Pengaruh Signifikan Dan Hasil Belajar Siswa.

\section{PENDAHULUAN}

\section{Latar Belakang Masalah}

Biologi merupakan ilmu dasar yang mempunyai peranan penting dalam perkembangan ilmu pengetahuan dan teknologi. Banyak siswa di sekolah memandang biologi sebagai bidang studi yang paling sulit karena harus menghapal. Biasanya, proses pembelajaran yang digunakan di sekolah-sekolah adalah pembelajaran yang berpusat pada guru. Siswa masih belum aktif dalam kegiatan pembelajaran karena selama pembelajaran guru banyak memberikan ceramah tentang materi. Diskusi antar kelompok jarang dilakukan sehingga interaksi dan komunikasi antara siswa dengan siswa lainnya maupun dengan guru masih belum terjalin selama proses 
pembelajaran. Sebagian besar siswa mengalami kesulitan dalam menyelesaikan soal -soal pada materi metabolisme maupun sintesis protein. Kesulitan siswa dalam menyelesaikan soal karena pada materi tersebut penuh dengan penggunaan rumus dalam perhitungan. Sementara itu proses belajar mengajar pada materi metabolisme, guru lebih sering menjelaskan materi melalui ceramah, siswa cenderung pasif, dan aktivitas siswa yang sering dilakukan hanya mencatat dan menyalin. Siswa masih malu bertanya kepada guru jika mengalami kesulitan dalam memahami atau menyelesaikan soal yang diberikan, akibatnya hasil belajar siswa pada materi metabolisme belum maksimal. Berdasarkan masalah tersebut peneliti berpendapat perlunya dilakukan perbaikan proses pembelajaran pada kelas tersebut. Hal ini dilakukan dengan tujuan agar siswa dapat ikut berperan aktif selama proses pembelajaran berlangsung. Siswa saling bertukar pendapat dalam memahami konsep metabolisme serta mampu menyelesaikan soal secara berdiskusi dalam kelompok. Maka diperlukan model pembelajaran yang dapat mengaktifkan siswa selama kegiatan belajar mengajar. Model pembelajaran yang lebih mendorong keaktifan, kemandirian dan tanggung jawab dalam diri siswa adalah model pembelajaran kooperatif tipe STAD. Melalui penerapan model pembelajaran kooperatif tipe STAD diharapkan dapat meningkatkan keaktifan dan prestasi belajar siswa pada materi stoikiometri. Sesuai dengan uraian diatas maka peneliti mengadakan penelitian dengan judul "PENINGKATAN KUALITAS PEMBELAJARAN BIOLOGI DENGAN METODE KOOPERATIFdi PRODI PEND. FISIKA FKIP UHN MEDAN". Penelitian ini dilakukan untuk mengetahui apakah pembelajaran kooperatif tipe STAD dapat meningkatkan keaktifan dan prestasi belajar siswa pada materi metabolisme matakuliah biologi umum.

\section{Perumusan Masalah}

Berdasarkan uraian diatas rumusan masalah yang diajukan dalam penelitian tindakan kelas ini adalah:

1. Apakah penerapan model pembelajaran kooperatif tipe STAD dapat meningkatkan keaktifan belajar siswa pada materi metabolisme di prodi fisika semester I ?

2. Apakah penerapan model pembelajaran kooperatif tipe STAD dapat meningkatkan prestasi belajar siswa pada materi metabolisme di prodi fisika semester I.

Received April 20 $0^{\text {th }}$ 2020; Revised May 26 $6^{\text {th }}$,2020; Accepted June $1^{\text {st }}, 2020$ 


\section{Tujuan dan manfaat}

Berdasarkan rumusan masalah di atas, tujuan penelitian tindakan kelas ini adalah:

1. Meningkatkan keaktifan belajar siswa pada materi metabolisme di prodi pend. Fisika semester I melalui penerapan model pembelajaran kooperatif tipe STAD.

2. Meningkatkan prestasi belajar siswa pada materi metabolisme melalui penerapan model pembelajaran kooperatif tipe STAD.

\section{Manfaat Penelitian}

Hasil penelitian tindakan kelas ini diharapkan dapat memberikan manfaat yaitu:

1. Bagi Guru sebagai bahan pertimbangan dalam menentukan model pembelajaran dengan tujuan agar dapat meningkatkan keaktifan dan prestasi belajar siswa.

2. Bagi Siswa sebagai wahana baru dalam proses meningkatkan keaktifan dan prestasi dalam pembelajaran biologi.

3. Bagi Peneliti sebagai pengembangan pengetahuan tentang penelitian dalam pembelajaran biologi.

Hasil penelitian yang didapat diharapkan memberi manfaat sebagai berikut:

1. Memberikan pengetahuan tentang karakteristik perpindahan panas loop thermosyphon yang terbuat dari pipa selubung tembaga dan fuida kerja berupa refrigeran R-134a sebagai alat recovery panas temperatur rendah.

2. Hasil penelitian ini dapat diterapkan pada industri pengeringan maupun industri yang memanfaatkan alat recovery panas sebagai alat penukar kalor yang fleksibel, murah, ekonomis dalam penggunaanya (tidak memerlukan pompa, kompresor, ataupun peralatan lain untuk menggerakkan fluida kerja), dan mudah dalam perawatannya.

\section{LANDASAN TEORI}

\section{Pengertian Belajar}

Menurut Hintzman belajar merupakan suatu perubahan yang terjadi dalam diri manusia disebabkan oleh pengalaman yang dapat mempengaruhi tingkah laku manusia (Muhibbin Syah, 2005). Kegiatan belajar merupakan unsur yang sangat mendasar dalam setiap penyelenggaraan jenis dan jenjang pendidikan. Jadi perubahan yang ditimbulkan oleh pengalaman baru dapat 
dikatakan belajar apabila mempengaruhi prilaku dalam kehidupan sehari-hari sampai batas tertentu. Menurut Oemar Hamalik (2003) beberapa unsur-unsur yang terkait dalam proses belajar diantaranya: 1) motivasi siswa, 2) bahan belajar, 3) alat bantu belajar, 4) suasana belajar, 5) kondisi subjek yang belajar. Kelima unsur inilah yang bersifat dinamis yang sering berubah dan mempengaruhi proses belajar siswa. Proses belajar pada hakekatnya merupakan perubahan dalam tingkah laku seseorang dalam situasi tertentu yang berulang-ulang berdasarkan keadaan seseorang. Perbuatan belajar adalah suatu perubahan yang ditimbulkan oleh pengalaman baru yang mempengaruhi tingkah laku siswa dalam situasi tertentu yang berulang-ulang. Setiap perbuatan belajar mengandung beberapa unsur yang bersifat dinamis (berubah-ubah) dalam arti dapat menjadi lebih kuat atau melemah. Kedinamisan ini dipengaruhi oleh kondisi yang ada dalam diri siswa dan yang ada diluar diri siswa yang tentu pula ada pengaruhnya terhadap kegiatan belajar siswa. 2. Pembelajaran Kooperatif Pembelajaran kooperatif menggunakan sistem pengelompokan yang terdiri empat sampai enam orang yang mempunyai kemampuan akademik, jenis kelamin, suku yang heterogen (Wina Sanjaya, 2007:240). Pada proses pembelajarannya siswa diberi kesempatan bekerja dalam kelompok kecil untuk mendiskusikan dan memecahkan masalah. Tugas kelompok dapat memacu para siswa untuk bekerja sama dalam mengintegrasikan pengetahuan baru dengan pengetahuan yang telah dimilikinya.

\section{Pembelajaran Kooperatif}

Pembelajaran Kooperatif merupakan model pembelajaran yang mengutamakan kerjasama diantara siswa untuk mencapai tujuan pembelajaran. Menurut Depdiknas (2005:14), model pembelajaran kooperatif mempunyai ciri-ciri antara lain: a. Untuk menuntaskan materi belajarnya, siswa belajar dalam kelompok secara kooperatif. b. Kelompok dibentuk dari siswasiswa yang memiliki kemampuan tinggi, sedang dan rendah. c. Jika dalam kelas terdapat siswasiswa yang terdiri dari beberapa ras, suku, budaya, jenis kelamin yang berbeda. Maka diupayakan agar dalam tiap kelompok terdiri dari ras, suku, budaya, jenis kelamin yang berbeda pula. d. Penghargaan lebih diutamakan pada kerja kelompok dari pada perorangan.

Untuk penguasaan materi pelajaran setiap siswa dalam kelompok bertanggung jawab secara bersama dengan cara berdiskusi, saling tukar pendapat, pengetahuan dan pengalaman. Kemampuan atau prestasi setiap anggota kelompok sangat menentukan hasil pencapaian belajar 
kelompok, untuk itu penguasaan materi pelajaran setiap siswa ditekankan dalam strategi pembelajaran kooperatif. Dengan model pembelajaran kooperatif diharapkan siswa dapat mengembangkan semua potensinya secara optimal dengan cara berpikir aktif selama proses belajar berlangsung. Menurut Depdiknas (2005:15) pengelolaan pembelajaran dengan menggunakan strategi pembelajaran kooperatif, paling tidak ada tiga tujuan yang hendak dicapai yaitu:

a. Hasil belajar akademik Pembelajaran kooperatif bertujuan meningkatkan kinerja siswa dalam tugas akademik. Banyak ahli berpendapat bahwa model kooperatif unggul dalam membantu siswa dalam memahami konsep-konsep yang sulit.

b. Pengakuan adanya keragaman Model kooperatif bertujuan agar siswa dapat menerima teman-temannya yang mempunyai berbagai macam perbedaan latar belakang. Perbedaan tersebut antara lain perbedaan suku, agama, kemampuan akademik, dan tingkat sosial.

c. Pengembangan keterampilan sosial Pembelajaran kooperatif bertujuan untuk mengembangkan keterampilan siswa. Keterampilan sosial yang dimaksud antara lain: berbagi tugas, aktif bertanya, menghargai pendapat orang lain, mau menjelaskan ide atau pendapat, dan bekerja dalam kelompok.

Dalam pembelajaran kooperatif terdapat enam langkah pembelajaran (Ismail, 2003:21) yaitu:

a. Menyampaikan tujuan dan memotivasi siswa. Guru meyampaikan semua tujuan pelajaran yang ingin dicapai pada pelajaran tersebut dan memotivasi siswa belajar.

b. Menyajikan informasi. Guru menyajikan informasi kepada siswa dengan jalan demontrasi atau lewat bahan bacaan.

c. Mengorganisasikan siswa kedalam kelompok-kelompok belajar. Guru menjelaskan kepada siswa bagaimana caranya membentuk kelompok belajar dan membantu setiap kelompok agar melakukan transisi secara efisien.

d. Membimbing kelompok bekerja dan belajar. Guru membimbing kelompok-kelompok belajar pada saat mereka mengerjakan tugas.

e. Evaluasi Guru mengevaluasi hasil belajar tentang materi yang telah dipelajari atau masing-masing kelompok mempresentasikan hasil kerjanya. 
f. Memberikan penghargaan. Guru mencari cara-cara untuk menghargai upaya atau hasil belajar individu maupun kelompok. Bila diperhatikan langkah-langkah model pengajaran kooperatif di atas maka tampak bahwa proses demokratis dan peran aktif siswa di kelas lebih banyak. Kendala yang dihadapi dalam penerapan model pembelajaran kooperatif adalah siswa yang pandai merasa terbebani oleh temannya yang kurang pandai. Siswa yang pandai akan merasa memberikan kontribusi lebih banyak dalam nilai kelompok. Hal ini dapat diatasi dengan menginformasikan sistem penilaian kepada siswa lebih dahulu sebelum pembelajaran dimulai.

Menurut Slavin (1995:80) salah satu cara perhitungan dalam penentuan nilai perkembangan siswa sebagai berikut: Langkah 1 : Menetapkan skor dasar Setiap siswa diberikan skor dasar berdasarkan skor kuis sebelumnya. Langkah 2 : Menentukan skor kuis terkini Siswa memperoleh skor dari kuis yang berkaitan dengan materi terkini. Langkah 3 : Menghitung skor perkembangan. Setiap siswa memperoleh poin peningkatan individu yang besarnya dihitung dari selisih skor sekarang dan skor dasar. Poin tersebut ditentukan dengan menggunakan skala berikut:

Tabel 1. Kriteria Poin Perkembangan

\begin{tabular}{|c|l|c|}
\hline No & \multicolumn{1}{|c|}{ Keterangan } & Nilai \\
\hline 1 & Perkembangan lebih dari 10 poin di bawah skor dasar & 5 poin \\
\hline 2 & Perkembangan 10 poin hingga 1 poin di bawah skor dasar & 10 poin \\
\hline 3 & Perkembangan dari skor dasar hingga 10 poin diatas skor dasar & 20 poin \\
\hline 4 & Perkembangan lebih dari 10 poin dari skor dasar & 30 poin \\
\hline 5 & Pekerjaan sempurna tanpa melihat skor dasar & 30 poin \\
\hline
\end{tabular}

Sumber: (Slavin, 1995:80)

\section{Pembelajaran Kooperatif Tipe STAD}

Sebuah tim dalam STAD merupakan sebuah kelompok terdiri dari empat atau lima siswa yang mewakili heteroginitas kelas ditinjau dari kinerja, suku, dan jenis kelamin. Menurut Mohamad Nur (2005) STAD terdiri dari lima komponen utama yaitu presentasi kelas, kerja tim, kuis, skor perbaikan individu dan penghargaan tim.Adapuntahapandalam model pembelajarantipe STAD adalah: 
- Presentasi Kelas. Presentasi ini paling sering menggunakan pengajaran langsung atau ceramah yang dilakukan oleh guru namun presentasi dapat meliputi presentasi audiovisual atau penemuan kelompok (Mohamad Nur, 2005:20). Pada kegiatan ini siswa harus sungguh-sungguh memperhatikan presentasi kelas karena dengan begitu akan membantu mereka mengerjakan kuis dengan baik. Dan skor kuis yang mereka peroleh akan menentukan skor timnya.

- Kerja Tim. Dalam setiap kelompok terdiri dari empat atau lima siswa yang heterogen berdasarkan pretasi belajar, jenis kelamin dan suku. Setelah guru mempresentasikan materi, tim tersebut berkumpul untuk mempelajari materi yang sudah diberikan dengan menggunakan lembar kerja. Pada tahap kerja kelompok ini siswa secara bersama mendiskusikan masalah dan membantu antar anggota dalam kelompoknya. Kerja tim yang paling sering dilakukan adalah membetulkan setiap kekeliruan atau miskonsepsi apabila teman sesama tim membuat kesalahan.

- Kuis. Sejauh mana keberhasilan siswa dalam belajar dapat diketahui dengan diadakannya kuis oleh guru mengenai materi yang dibahas. Dalam mengerjakan kuis ini siswa harus bekerja secara individu sekalipun skor yang ia peroleh nanti dapat digunakan untuk menentukan keberhasilan kelompoknya. Kepada setiap individu, guru memberikan skor yang digunakan untuk menentukan skor bersama bagi setiap kelompok.

- Skor Perbaikan Individu. Skor yang diperoleh setiap anggota dalam kuis akan berkontribusi pada kelompok mereka, dan didasarkan pada sejauh mana skor mereka telah meningkat dibandingkan dengan skor rata-rata awal yang telah mereka capai sebelumnya (Isjoni dkk, 2007:72). Berdasarkan skor awal setiap individu ditentukan skor peningkatan atau perkembangan. Rata-rata skor peningkatan dari tiap individu dalam suatu kelompok akan digunakan untuk menentukan penghargaan bagi kelompok yang berprestasi.

- Penghargaan. Tim Kelompok dapat memperoleh sertifikat atau penghargaan lain apabila skor rata- rata yang didapat melampaui kriteria tertentu. Penghargaan yang diperoleh menunjukkan keberhasilan setiap kelompok dalam menjalin kerjasama antar anggota 
kelompok. Penghargaan kelompok dilakukan dengan memberikan penghargaan berupa sertifikat atau penghargaan lain atas usaha dan kerja keras yang dilakukan kelompok.

Menurut Mohamad Nur (2005:36) ada tiga tingkat penghargaan yang diberikan berdasarkan skor tim rata-rata. Ketiga tingkat adalah sebagai berikut:

Tabel 2. Kriteria Penghargaan Kelompok Kriteria (rata-rata tim)

\begin{tabular}{|c|c|c|}
\hline No & Skor & Predikat \\
\hline 1 & 15 & Tim Baik \\
\hline 2 & 20 & Tim Hebat \\
\hline 3 & 30 & Tim Super \\
\hline
\end{tabular}

Sumber: (Mohamad Nur, 2005:36)

\section{Keaktifan Siswa.}

Aktif menurut kamus besar bahasa Indonesia (2002:19) berarti giat (bekerja atau berusaha), sedangkan keaktifan diartikan sebagai hal atau keadaan dimana siswa dapat aktif. Keaktifan siswa dalam belajar matematika tampak dalam kegiatan berbuat sesuatu untuk memahami materi pelajaran. Menurut Moh User Usman (2002:26) cara yang dapat dilakukan guru untuk memperbaiki keterlibatan siswa antara lain sebagai berikut: a. Tingkatkan persepsi siswa secara aktif dalam kegiatan belajar mengajar yang membuat respon yang aktif dari siswa $b$. Masa transisi antara kegiatan dalam mengajar hendaknya dilakukan secara cepat dan luwes c. Berikan pengajaran yang jelas dan tepat sesuai dengan tujuan mengajar yang akan dicapai d. Usahakan agar pengajaran dapat lebih memacu minat siswa. Menurut Lidgren (Moh User Usman, 2002:24) terdapat empat jenis interaksi dalam kegiatan belajar mengajar diantaranya sebagai berikut:

- Komunikasi satu arah merupakan komunikasi yang hanya dilakukan oleh guru terhadap siswa, sementara siswa hanya pasif sebatas mendengarkan dari guru.

- Komunikasi dari guru sudah mendapat respon balik dari siswa, tetapi tidak ada interaksi antar siswa. Interaksi yang terjadi hanya antara guru dan siswa selama pembelajaran.

- Komunikasi dari guru sudah mendapat respon balik dari siswa dan ada interaksi diantara siswa, tetapi belum keseluruhan siswa yang melakukan interaksi baik dengan guru maupun siswa lainnya.

Received April 20 $0^{\text {th }}$ 2020; Revised May 26 $6^{\text {th }}$ 2020; Accepted June $1^{\text {st }}, 2020$ 
- Komunikasi sudah berjalan baik antara guru dengan siswa maupun antara siswa dengan siswa lainnya. Dalam hal ini interaksi sudah optimal selama proses pembelajaran.

Jenis-jenis interaksi pembelajaran diatas menunjukkan derajat keaktifan siswa. Keaktifan siswa merupakan suatu keadaan dimana siswa berpartisipasi secara aktif dalam pembelajaran. Dalam hal ini keaktifan siswa terlihat dari merespon pertanyaan atau perintah dari guru, mendengarkan dan memperhatikan penjelasan guru, berani mengemukakan pendapat, dan aktif mengerjakan soal yang diberikan guru.

\section{Prestasi Belajar.}

Belajar merupakan salah satu dasar untuk mengetahui sejauh mana materi pelajaran yang disampaikan guru dapat diterima dan dipahami sehingga prestasi belajar siswa dapat diketahui dari hasil tes yang diberikan. Menurut Saifudin Azwar (1998:45) prestasi merupakan hasil yang telah dicapai dari apa yang telah dilakukan dan dikerjakan secara optimal. Menurut Dalyono (2005:55) ada beberapa faktor yang mempengaruhi prestasi belajar yaitu faktor intern dan faktor ekstern. Faktor intern meliputi kesehatan, intelegensi, bakat, minat, dan motivasi, sedangkan faktor ekstern meliputi keluarga, sekolah, masyarakat dan lingkungan sekitar. Faktor yang bersumber dari dalam diri siswa yaitu kecerdasan, minat, motivasi dan kemampuan kognitif sedangkan faktor dari lingkungan keluarga yaitu tingkat pendidikan orang tua dan jumlah anggota orang tua. Prestasi belajar siswa merupakan hasil yang telah dicapai siswa setelah belajar dan mengerjakan secara optimal yang diperoleh dari hasil tes individu. Perbedaan kemampuan belajar siswa berpengaruh pada prestasi belajar yang dicapai dari setiap siswa karena faktor yang mempengaruhi prestasi belajar siswa juga berbeda-beda.

\section{METODE PENELITIAN}

\section{Tempat dan Waktu Penelitian}

Penelitian ini dilakukan di prodi pend. Fisika semester I pada semester ganjil bulan Oktober sampai November 2018. Dengan menyesuaikan jam matakuliah Biologi umum Subyek penelitian ini adalah mahasiswa di prodi pend. Fisika semester I, yaitu 20 mahasiswa. Obyek penelitian ini adalah penerapan model pembelajaran kooperatif tipe STAD.

Received April 20 $0^{\text {th }}$, 2020; Revised May 26 $6^{\text {th }}$,2020; Accepted June $1^{\text {st }}, 2020$ 


\section{Desain Penelitian}

Penelitian ini adalah tindakan kelas yang dilakukan secara kolaboratif. Pihak yang melakukan tindakan adalah dosen itu sendiri sedangkan yang diminta melakukan pengamatan terhadap berlangsungnya proses tindakan adalah peneliti (Suharsimi Arikunto, 2002:17). Menurut Kemmis dan Taggart ada beberapa tahapan dalam penelitian ini (Rochiati Wiriaatmadja, 2005:66) yaitu: 1. Perencanaan (plan) 2. Tindakan (act) 3. Pengamatan (observe) 4. Refleksi (reflect).

Siklus dihentikan apabila kondisi kelas sudah stabil dalam hal ini guru sudah mampu menguasai keterampilan belajar yang baru dan siswa terbiasa dengan model pembelajaran kooperatif tipe STAD serta data yang ditampilkan di kelas sudah jenuh dalam arti sudah ada peningkatan keaktifan dan prestasi belajar siswa (Rochiati Wiriaatmadja, 2005:103).

Observasi. Dilakukan selama proses pembelajaran dengan menggunakan lembar observasi yang telah disiapkan dan mencatat kejadian-kejadian yang tidak terdapat dalam lembar observasi dengan membuat lembar catatan lapangan tentang kegiatan pembelajaran dan aktivitas guru maupun siswa selama pelaksanaan pembelajaran.

Refleksi. Pada tahap ini peneliti bersama dosen melakukan evaluasi dari pelaksanaan tindakan pada siklus I yang digunakan sebagai bahan pertimbangan perencanaan pembelajaran siklus berikutnya. Jika hasil yang diharapkan belum tercapai maka dilakukan perbaikan yang dilaksanakan pada siklus kedua dan seterusnya.

\section{Teknik Pengumpulan Data.}

Teknik pengumpulan data yang digunakan adalah: Observasi terdapat dua pedoman observasi yaitu observasi keaktifan siswa dan obsevasi pelaksanaan pembelajaran kooperatif tipe STAD. Tes adalah kuis individu untuk mengetahui tingkat pemahaman siswa setelah mempelajari materi himpunan dengan menggunakan model pembelajaran kooperatif tipe STAD. Dokumentasi diperoleh dari hasil kuis siswa, lembar observasi, lembar wawancara, catatan lapangan, daftar kelompok siswa, dan foto-foto selama proses pembelajaran.

Instrumen Penelitian: 1. Peneliti merupakan instrumen karena peneliti sekaligus sebagai perencana, pelaksana, pengumpul data, penganalisis, penafsir data dan pada akhirnya menjadi pelapor penelitiannya (Lexy J. Moleong 2007: 168) 2. Lembar Observasi Dalam penelitian ini 
digunakan dua lembar yaitu lembar observasi pelaksanaan pembelajaran kooperatif tipe STAD dan lembar keaktifan siswa. Lembar observasi pelaksanaan pembelajaran STAD digunakan sebagai pedoman peneliti dalam melakukan observasi pelaksanaan pembelajaran kooperatif tipe STAD. Sedangkan lembar observasi keaktifan siswa digunakan pada setiap pembelajaran.

\section{HASIL DAN PEMBAHASAN}

\section{Hasil}

\section{TABEL 3. DAFTAR NILAI MAHASISWAMATAKULIAH BIOLOGI UMUM}

\begin{tabular}{|c|c|c|}
\hline No & NilaiSiklus 1 & NilaiSiklus 2 \\
\hline 1 & 75 & 78 \\
\hline 2 & 78 & 82 \\
\hline 3 & 80 & 85 \\
\hline 4 & 75 & 78 \\
\hline 5 & 76 & 78 \\
\hline 6 & 60 & 70 \\
\hline 7 & 55 & 65 \\
\hline 8 & 75 & 80 \\
\hline 9 & 80 & 84 \\
\hline 10 & 83 & 90 \\
\hline 11 & 58 & 67 \\
\hline 12 & 61 & 80 \\
\hline 13 & 75 & 78 \\
\hline 14 & 81 & 85 \\
\hline 15 & 60 & 75 \\
\hline 16 & 80 & 85 \\
\hline 17 & 82 & 87 \\
\hline 18 & 81 & 83 \\
\hline 19 & 50 & 70 \\
\hline \multirow[t]{3}{*}{20} & 85 & 100 \\
\hline & 1323 & 1600 \\
\hline & 66,15 & 80,0 \\
\hline
\end{tabular}

Received April 20 $0^{\text {th }}$, 2020; Revised May 26 $6^{\text {th }}$,2020; Accepted June $1^{\text {st }}, 2020$ 
Penerapan model pembelajaran model STAD pada mata kuliahBiologi di prodi pend. Fisika untuk meningkatkan aktivitas mahasiswa dan hasil belajar mahasiswa. Berdasarkan penelitian, penelitian ini dilaksanakan sebanyak 2 siklus. Diperoleh hasil sebagai berikut:

Tabel 4. Penerapan Model Pembelajaran STAD Pada Mata Kuliah Biologi

\begin{tabular}{|c|c|c|c|c|c|c|}
\hline Siklus & $\begin{array}{c}\text { Rata-rata } \\
\text { Skor Aktivitas } \\
\text { Mhs }\end{array}$ & Kriteria & Jumlah Mhs & $\begin{array}{c}\text { Jumlah Mhs } \\
\text { Mendapat } \\
\text { Nilai } \geq 75\end{array}$ & $\begin{array}{c}\text { Nilai Rata- } \\
\text { rata }\end{array}$ & Kriteria \\
\hline 1 & 34,5 & Baik & 20 & 14 & 66,15 & Belum \\
\hline 2 & 37 & Baik & 20 & 18 & 80,0 & Tuntas \\
\hline
\end{tabular}

Rata-rata skor aktivitas mahasiswa pada siklus I diperoleh sebesar 34.5 dan meningkat menjadi 37 pada siklus II dengan kriteria baik. Nilai rata-rata siswa pada siklus I sebesar 66.15 dan persentase ketuntasan belajar klasikal 70.0\% dengan criteria belum tuntas,namun padasiklus II meningkat menjadi $80.0 \%$ dengan criteria tuntas. Proses pembelajaran dapat dikatakan baik apabila terjadi peningkatan terhadap aktivitas guru,aktivitas siswa,dan hasil belajar Pada siklus I masih terdapat banyak aspek pengamat anaktivitas mahasiswa yang belum bisa dilakukan dengan baik, namun pada siklus II aspek tersebut sudah diperbaiki. Peningkatan terhadap aspek pengamat anaktivitas mahasiswa terjadi karena adanya perbaikan kelemahan yang terjadi pada siklus sebelumnya.

Dosen mengalam ikesulitan pada saat membimbing mahasiswa melakukan diskusi. Kesulitan yang dialami karena mahasiswa belum terbiasa dengan model pembelajaran kooperatif tipe STAD akibatnya waktu yang digunakan untuk pembelajaran menjadi semakin lama.

Kelemahan dari STAD adalah pada saat pembelajaran tim membutuhkan waktu yang relative lama, sehingga mahasiswa yang memiliki kemampuan lebih akan merasa terhambat oleh mahasiswa lain yang memiliki kemampuan dibawahnya.

Dari pengamatan yang dilakukan, dicatat jumlah mahasiswa yang menjawab dengan benar pertanyaan yang diajukan oleh dosen, mahasiswa tidak mencatat informasi penting yang disampaikan oleh dosen mengenai materi pokok yang dipelajari, mahasiswa yang mampu

Received April 20 ${ }^{\text {th }}$, 2020; Revised May 26 ${ }^{\text {th }}$,2020; Accepted June $1^{\text {st }}, 2020$ 
menjawab pertanyaan hanya 4 kelompok. Kelompok yang menang pada turnamen hanya memperoleh pengakuan tetapi tidak memperoleh penghargaan diakhir pelajaran.

Aspek pengamatan ini akan diperbaiki pada siklus II dengan memberikan penghargaan kepada kelompok yang memperoleh skor tertinggi.

Kelemahan-kelemahan yang ditemukan pada aktivitas mahasiswa dapat dikurangi dengan cara dosen memberikan tugas kepada mahasiswa pada minggu sebelumnya untuk membaca materi berikutnya sehingga mahasiswa telah mengetahui dasar-dasar materi yang akan mereka pelajari. Dosen memusatkan perhatian mahasiswa agar lebih menyimak informasi yang telah disampaikan, kemudian mengarahkan mahasiswa untuk mencatat informasi tersebut dan akan menilai catatan siswa di setiap minggunya. Hal ini untuk memotivasi mahasiswa untuk aktif dalam pembelajaran dikelas dan tiap kelompok akan berlomba menjadi yang terbaik yang kemudian akan mendapat penghargaan (Prasetyaningrum, Martini \&Susilowati, 2013).

Peningkatan juga terjadi pada hasil belajar dari siklus I ke siklus II dan proses pembelajaran mencapai ketuntasan belajar klasikal pada siklus II. Berdasarkan analisa soal post test, pemahaman mahasiswa terhadap materi pelajaran meningkat padasiklus II (Tabel2). Persen mahasiswa yang menjawab benar pada soaltingkat kognitif C3/ Penerapan meningkat dari 50\% menjadi $80 \%$.

Pada siklus I, analisa soal post test menunjukkan bahwa dari 7 soal posttest yang disusun oleh dosen, soal no. 6 merupakan soal yang paling banyak di jawab benar oleh siswa yakni sebesar 100\%. Soal no. 6 ini merupakan soal tingkat kognitif C1 yaitu mahasiswa diminta untuk menyebutkan pengertian dari istilah metabolisme. Soal yang paling banyak dijawab salah oleh mahasiswa adalah soal no 4, mahasiswa yang menjawab benarhanya 50\%. Soal no 4 ini merupakan soal tingkat kognitif C3 yaitu mahasiswa diminta untuk menjelaskan mengapa proses metabolisme penting dalam kehidupan mahluk hidup. Kesulitan mahasiswa dalam menjawab soal no 4 disebabkan karena tingkat kesukaran soal yaitu penerapan.

Analisa soal post test siklus II menunjukkan bahwa dari7 soal post test yang dibuat oleh dosen,soal no1 dan 6 merupakan soal yang 100\% dijawab benar oleh mahasiswa. Soal-soal tersebut merupakan soal tingkat kognitif C1 yaitu tingkat pengetahuan. Soal yang paling Banyak dijawab salah oleh mahasiswa adalah soal no 7 , hanya $60 \%$ mahasiswa yang menjawab 
benar.Soal no 7 ini, mahasiswa diminta untuk membedakan anabolisme dengan katabolisme serta memberikan contohnya. Kesulitan siswa pada saat menjawab soal no 7 ini disebabkan karenakurangnya perhatian mahasiswa terhadap proses pembelajaran baik pada saat penyajian materi oleh dosen maupun pada saat diskusi. Faktor lainnya yaitu tingkat kesukaran soal no 7 yakni tingka tkognitif C3. Namun secara keseluruhan pembelajaran dengan menerapkan model pembelajaran kooperatif tipe STAD pada pokok bahasan metabolisme dapat meningkatkan ketuntasan belajar mahasiswa.

Meningkatnya ketuntasan belajar mahasiswa dengan menerapkan model pembelajaran kooperatif tipe STAD dikarenakan pada pembelajaran inimahasiswa lebih termotivasi untuk belajar, mahasiswa bisa berdiskusi dan bekerjasama saling membantu teman sekelompoknya yang memiliki kemampuan akademik lebih rendah, sehingga mereka secara bersama bisa menuntaskan bahan ajar yang mereka pelajari. Hal ini sesuai dengan pendapat Nur(2005) yang menyatakan bahwa dengan menerapkan model pembelajaran kooperatif tipe STAD mahasiswa lebih memahami konsep dalam pembelajaran biologi, lebih meningkatkan kerjasama antar mahasiswa, lebih termotivasi untuk belajar, lebih mengingat dan memahami apa yang telah di pelajari, mahasiswa merasa belajar itu tidak membosankan karena bentuk evaluasi dalam pembelajaran ini yang cukup menyenangkan bagi mahasiswa.

Penerapan model pembelajaran kooperatif tipe STAD dapat meningkatkan aktivitas mahasiswa. Peningkatan aktivitas tersebut berdampak positif terhadap peningkatan ketuntasan belajar mahasiswa secara klasikal. Hal ini relevan dengan pendapat Kusumandari (2011), yang menyatakan: penerapan model pembelajaran kooperatif tipe STAD dapat meningkatkan motivasi dan hasil belajar mahasiswa pada materi metabolisme.

\section{KESIMPULAN}

Pembelajaran dengan menerapkan model pembelajaran kooperatif tipe STAD selama proses pembelajaran biologi pada pokok bahasan metabolism dapat meningkatkan aktivitas, dan hasil belajar mahasiswa diprodi fisika semester 1, T.A. 2018/2019. Aktivitas mahasiswa pada siklus I diperoleh rata-rata skor 34.5 dengan criteria baik, kemudian pada siklus II rata-rata skor meningkat menjadi 37 dengan criteria baik. Peningkatan juga terjadi pada hasil belajar 
mahasiswa dengan persentase ketuntasan belajarsiklus $66,15 \%$ dengan criteria belum tuntas dan pada siklus I Isebesar 80,0\% dengan criteria tuntas.

\section{DAFTAR PUSTAKA}

Etin Solihatin dan Raharjo., 2007, Cooperatif Learning: Analisis Model Pembelajaran IPS, Jakarta: Bumi Aksara

Ismail. 2003, Model Pembelajaran Kooperatif, Dit. PLP Dikdasmen.

Lexy J Moleong. 2007, Metodologi Penelitian Kualitatif, Bandung: Remaja Rosdakarya.

Moh User Usman,. 2002, Menjadi Guru Profesional, Bandung: Remaja Rosdakarya.

Mohamad Nur. 2005., Pembelajaran Kooperatif, Dirjen Dikti Depdiknas.

Muhibbin Syah. 2005., Psikologi Pendidikan: Dengan Pendekatan Baru, Bandung: Remaja Rosdakarya.

Oemar Hamalik. 2003., Kurikulun dan Pembelajaran, Jakarta: Bumi Aksara. Ponco Sujatmiko. 2005.

Rochiati Wiriaatmadja. 2005., Metode Penelitian Tindakan Kelas, Bandung: Remaja Rosdakarya.

Robert E Slavin. 1995., Cooperative Learning Theory Research and Practise.Boston : Allyn and Bacon, Saifudin Azwar. 1998. Tes Prestasi II. Yogyakarta: Pustaka Pelajar.

Suharsimi Arikunto. 2002., Penelitian Tindakan Kelas, Jakarta: Bumi Aksara.

Sugiyono. 2001., Metode Penelitian Administrasi, Bandung: Alfabeta. Tintin Prihatiningsih. 2006.

Wina Sanjaya. 2007., Strategi Pembelajaran Kooperatif: Berorientasi Standar Proses Pendidikan, Jakarta 